Article

\title{
Concrete Damage in Field Conditions and Protective Sealer and Coating Systems
}

\author{
Md. Safiuddin \\ Angelo Del Zotto School of Construction Management, George Brown College, 146 Kendal Avenue, \\ Toronto, ON M5T 2T9, Canada; safiq@yahoo.com; Tel.: +1-416-415-5000 (ext. 6692)
}

Received: 23 May 2017; Accepted: 24 June 2017; Published: 29 June 2017

\begin{abstract}
Concrete structures undergo different forms of damage during their service life. The aim of this study is to identify the most common forms of concrete damage in field conditions. A number of concrete elements and structures were visually inspected and the damage was photographed. The damage phenomena covered are delamination, popout, spalling, scaling, drying shrinkage cracking, corrosion-induced cracking, map cracking, rust and salt stains, discoloration, and mold and moss growths. The probable reasons for these damage phenomena are discussed in this study. Moreover, this study highlights how concrete structures can be protected from the aforementioned forms of damage by using sealer and coating systems as surface treatments. Different sealer and coating systems, emphasizing their selection for specific uses, installation on concrete substrate, effects on concrete durability, performance criteria, and performance evaluation methods have been discussed. Furthermore, some recommendations are given to improve the performance of concrete sealer and coating systems for the protection of concrete structures in field conditions.
\end{abstract}

Keywords: coating; concrete damage; sealer; protective measures

\section{Introduction}

Concrete is one of the most widely used construction materials because of its affordability and versatility. However, concrete is not an indestructible construction material; different forms of damage occur over time under service and environmental conditions, causing cosmetic and structural flaws in concrete structures [1]. Consequently, the performance of concrete structures gets affected during their service life. The level of damage in concrete structures depends on the severity of surrounding environment, the mix composition of concrete, and the degree of quality control during concrete construction [2-4]. The climatic conditions in many regions of the world are not very favorable for concrete structures. In many countries, the construction of durable concrete structures is very challenging for builders due to harsh winter and/or hot summer climates.

Concrete structures globally undergo different forms of attack from environmental influences such as wetting and drying, freezing and thawing, and extreme temperature changes [5-9]. Many environmental attacks become more severe for concrete in the presence of chloride and sulfate ions sourced from anti-icing or de-icing salts and seawater/soil, respectively [10-14]. Under such aggressive environmental exposures, concrete structures require special attention to the factors influencing durability, so that they can provide an acceptable span of service life. Without this consideration, concrete structures may experience accelerated damage such as surface scaling, spalling, and corrosion-induced cracking [12,13,15-19].

The durability performance of the reinforced concrete primarily depends on the composition and properties of its exposed surface layer or covercrete [20]. Many forms of damage start on the surface layer of concrete. Coatings and sealers are often used to protect the surface layer of concrete by retarding the ingress of water and water-laden harmful agents such as chlorides $(\mathrm{NaCl}$, 
$\mathrm{CaCl}_{2}, \mathrm{MgCl}_{2}$, etc.), sulfates $\left(\mathrm{Na}_{2} \mathrm{SO}_{4}, \mathrm{~K}_{2} \mathrm{SO}_{4}, \mathrm{CaSO}_{4}, \mathrm{MgSO}_{4}\right.$, etc.), and carbon dioxide [21-32]. Darwin et al. [11], Kozikowski et al. [14], and Sutter et al. [15] reported that $\mathrm{CaCl}_{2}$ and $\mathrm{MgCl}_{2}$ can cause severe scaling of concrete, which not only damages the concrete surface but also accelerates the ingress of deleterious agents more deeply into concrete and increases its degree of saturation $[17,18]$. Chlorides can subsequently penetrate the concrete cover (covercrete) more rapidly [17], while carbon dioxide can more easily diffuse from the atmosphere [32], both thus contributing to the corrosion of reinforcing steel [33]. Moreover, the increased degree of saturation causes strength loss due to the formation of ice that causes cracking in concrete [9].

Surface treatments such as sealers, coatings, membranes, and impregnation resins are currently used for the protection of concrete structures [23,33,34]. Sealers or coatings are applied on concrete surfaces to protect the underlying concrete. In infrastructure projects, they are used for the protection of bridge components and pavement. Their main purpose is to reduce the penetration of water, de-icing or anti-icing salts, and deleterious gases such as carbon dioxide into concrete. A review of the literature shows that surface treatments by sealers or coatings can significantly improve the durability of concrete and thus extend the service life of concrete bridges [34-38]. Palle and Hopwood II [34] reported that an appropriate sealer or coating system can protect the structural concrete from corrosion and de-icing salt damage by inhibiting chloride penetration. Wenzlick [35] and Attanayaka et al. [36] examined the role of sealers in bridge deck protection. Pritzl et al. [38] focused the performance of penetrating sealers to prevent chloride penetration into bridge deck. They observed that the durability performance of bridge deck is greatly improved when sealers are applied on concrete surfaces.

Identifying different forms of concrete damage and understanding the damage mechanisms correctly could be useful in selecting appropriate sealer and coating systems for the protection of concrete structures. The main objective of this study was to identify different forms of concrete damage in concrete structures under field conditions. A number of concrete elements and structures were visually inspected. The concrete damage was identified and photographed. The possible causes of the damage and the preventive measures have been discussed. The role of sealer and coating systems has been emphasized to protect concrete structures from the damage phenomena as identified during field observations. In addition, the installation techniques of sealer and coating systems as well as their beneficial effects and performance criteria have been discussed in this paper. Above all, some recommendations are given to enhance the performance of concrete sealer and coating systems in field conditions.

\section{Damage of Concrete}

Concrete damage occurs during the service life of concrete structures due to physical and chemical attacks driven by aggressive environments. The physical damage of concrete caused by freezing and thawing actions is very common in many winter-region countries. The damaging effects of freezing and thawing such as surface scaling and internal frost damage of concrete are greatly intensified in the presence of de-icing salts used in road maintenance during winter [13,39]. In addition, wetting and drying coupled with de-icing chemicals can often cause significant physical damage in concrete [10,11].

De-icing salts such as $\mathrm{NaCl}, \mathrm{CaCl}_{2}$ and $\mathrm{MgCl}_{2}$ are used in many countries during winter to maintain safe driving conditions. Darwin et al. [11], Sutter et al. [15], and Kozikowski et al. [14] reported that $\mathrm{CaCl}_{2}$ and $\mathrm{MgCl}_{2}$ de-icing salts cause severe scaling of concrete, thus significantly damaging the surface layer of concrete. The damage on the concrete surface allows chlorides to penetrate the concrete more rapidly and carbon dioxide to diffuse more easily from the surrounding environment; hence, both could result in more corrosion of the reinforcing steel embedded in concrete. In addition, the damaged concrete surface allows more water to enter the concrete; consequently, the degree of concrete saturation increases and it can cause a loss of strength due to the formation of ice [9].

Field observations conducted by the author of the present study revealed that concrete undergoes many different forms of damage during its service life, depending on the nature and severity of aggressive environment. Some common forms of damage are scaling, spalling, popout, delamination 
or mortar flaking, drying shrinkage cracking, map cracking or crazing, corrosion-induced cracking, rust and salt stains, discoloration, and mold and moss growths. These types of concrete damage are discussed in the following sub-sections, emphasizing the damaging factors, damage mechanisms, and preventive measures.

\subsection{Scaling}

Scaling is the flaking of the surface of hardened concrete to a depth of roughly $\frac{1}{4}$ to $\frac{1}{2}$ inches $(6-13 \mathrm{~mm})$, as shown in Figure 1. It is the general loss of surface mortar exposed to freezing and thawing environment. This is a common problem in winter-region countries. In this problem, the aggregates become clearly exposed on many spots of the concrete surface (refer to Figure 1) and most often stand out from the concrete.

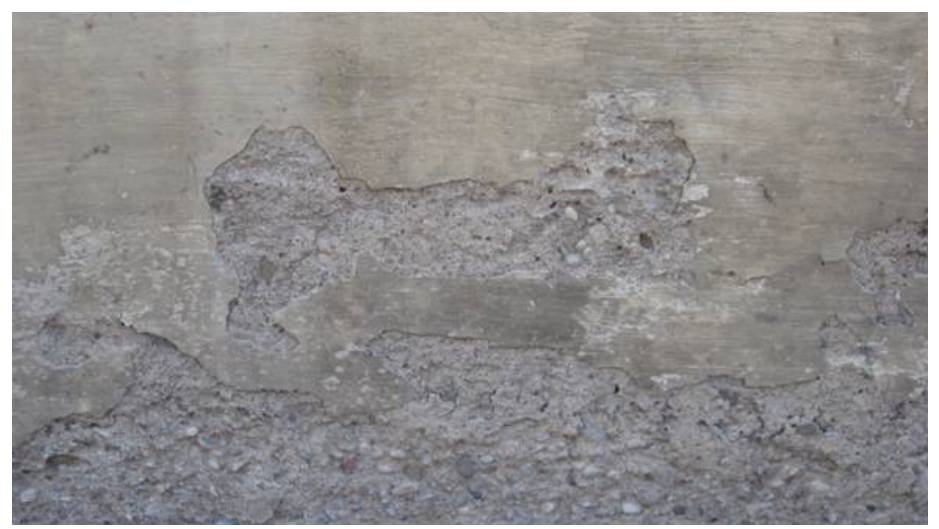

Figure 1. Severe surface scaling on the concrete foundation wall of a residential building.

Scaling is mainly caused by the pressure exerted by the solid ice formed within the concrete pore network [40]. When this pressure exceeds the tensile strength of concrete, scaling occurs. Excessive surface finishing, deicing salts, and freeze-thaw cycles as well as the presence of poor aggregates aggravate concrete scaling. The presence of fly ash has also been linked to a possible worsening of concrete scaling [41]. The other factors contributing to scaling are high porosity or low strength of covercrete, insufficient curing, and the absence of air-voids in concrete. The prolonged freeze-thaw cycles cause the concrete to scale if it does not have enough strength or entrained air-voids. De-icing or anti-icing chemicals may increase the degree of scaling on concrete, due to the formation of certain solids that induce more expansive pressure on covercrete [42].

De-icing chemicals aggravate the surface scaling of concrete. The effect of de-icing chemicals on the surface scaling of concrete has been reported in technical literature [10-12,43]. Sutter et al. [15] as well as Hooton and Julio-Betancourt [12] reported that $\mathrm{NaCl}$ is more deleterious than $\mathrm{CaCl}_{2}$ and $\mathrm{MgCl}_{2}$ in causing surface scaling of concrete because it has the highest rate of permeation into concrete. Hooton and Julio-Betancourt [12] observed that 3\% NaCl solution causes more scaling on concrete surfaces than $3 \% \mathrm{MgCl}_{2}$ solution; they recorded the lowest mass loss due to scaling in the cases of $\mathrm{CaCl}_{2}$ and $\mathrm{MgCl}_{2}$ de-icing chemicals.

To prevent the surface scaling of concrete, the proper concrete mix with durable and well-graded aggregates should be used. In addition, an adequate air content needs to be used in the concrete mix. Usually, a minimum of $6 \%$ (sometimes $6.5 \%$ ) air is recommended to avoid scaling [44]. However, $5 \%$ air may be adequate but further precautions are required. Furthermore, proper curing must be provided immediately after finishing the poured concrete. Appropriate drainage should also be taken into consideration; the water needs to be drained away from the concrete surface. This is because a saturated concrete surface is more prone to be damaged than a dried concrete surface. Moreover, the use of de-icing chemicals should be minimized or a special type of chemical producing the least effect on the concrete surface should be used to limit concrete damage. A sealer or coating can also 
be applied on new concrete to prevent surface scaling by reducing the ingress of water and de-icing chemicals into concrete.

In the case of old concrete, the surface scaling problem can be resolved by refinishing the concrete surface with a superior paste or mortar finish followed by proper curing. In extreme cases, the whole scaled section of concrete can be replaced using a properly mixed concrete mix. To achieve better protection, the entire concrete surface, including repaired sections, should be treated with an effective surface sealer or coating product.

\subsection{Spalling}

Spalling is defined as a deep surface defect of concrete that often occurs on bridge abutment walls, on building walls, floors or roofs, and under concrete bridge decks, as shown in Figure 2. The surface becomes flaky and the pieces of concrete break off. Concrete can also crack, particularly when large pieces break off. Spalling can be cosmetic at a low level but it may cause serious structural damage over time if ignored. Even if the damage is purely cosmetic, spalling can be a problem too because it alters the appearance of concrete structures.

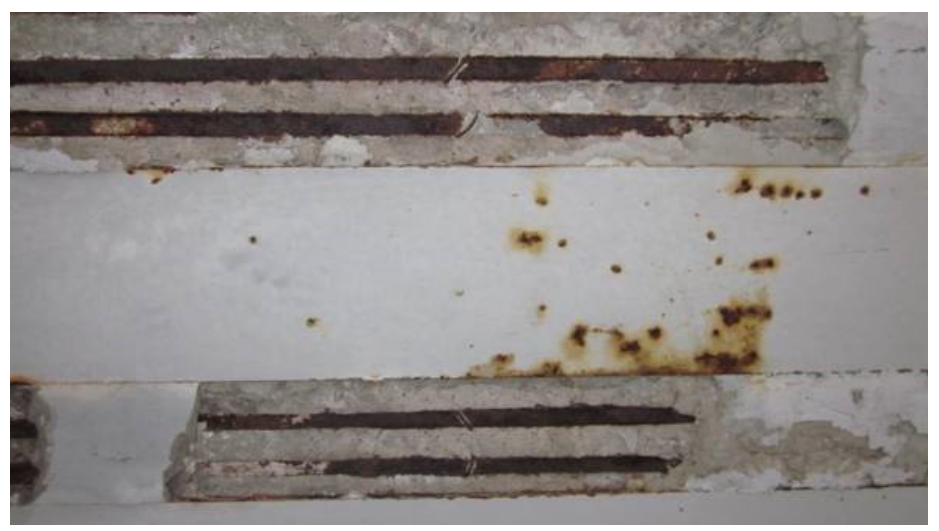

Figure 2. Severe spalling of concrete from the soffit of a composite bridge deck.

Spalling of concrete occurs when it undergoes expansive force. The expansive force in concrete may results from the corrosion of reinforcing steel, extreme temperature changes, fire, and weathering actions $[4,43,45]$. It can also be due to the combined effect of poor installation and miscalculated or unforeseen environmental factors as well as impact loads like blast [45,46]. Furthermore, the bond failure in two-course construction and improperly constructed joints can cause the spalling of concrete [45].

Concrete spalling can be minimized by using corrosion-resistant reinforcement such as stainless steel, epoxy-coated, or composite rebars. The use of low-permeability concrete and the addition of waterproofing sealer or coating will also decrease concrete spalling. The low-permeability concrete reduces the penetration of water into concrete and thus can help to decrease the corrosion of steel reinforcement. The low amount of water with a relatively high amount of cement at a water-to-cement ratio of $\leq 0.40$ should be used to produce low-permeability concrete. Employing a proper curing, preferably moist or wet curing, is also vital to make the covercrete impervious to water. On the other hand, surface film-forming sealer or coating systems act as a barrier to prevent deleterious agents such as saltwater and carbon dioxide from entering concrete that accelerate the corrosion of steel reinforcement. A penetrating sealer can also be used to reduce the corrosion-induced spalling of concrete. 


\subsection{Popout}

Popout occurs when the fragments of concrete break out leaving large visible holes on concrete surfaces. The size of holes in diameter may typically vary from 5 to $50 \mathrm{~mm}$, but can be up to $300 \mathrm{~mm}$ [45]. Over time, the popouts can become bigger and connected to cause severe damage on concrete surfaces in the form of potholes. This field problem most commonly occurs on rigid or concrete pavement surfaces, as shown in Figure 3. However, it may also occur on the untreated (unsealed or uncoated) concrete walls.

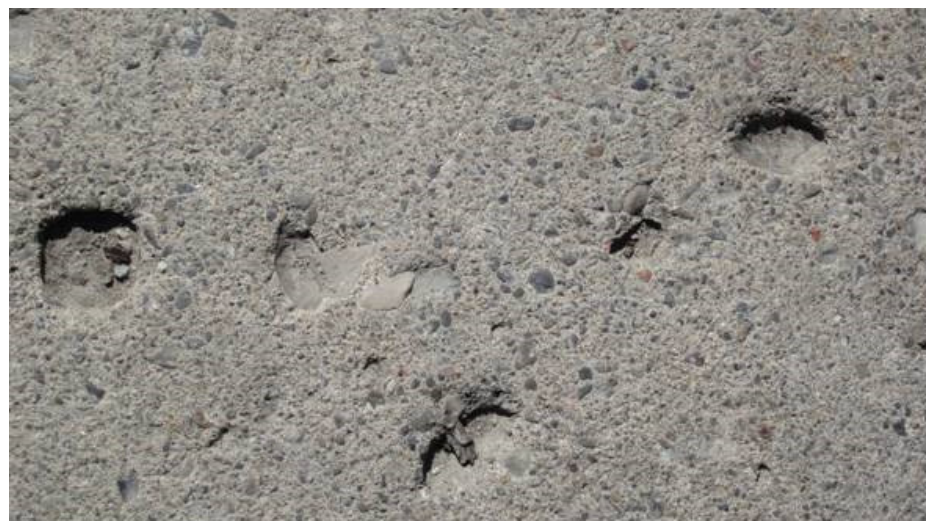

Figure 3. Moderate popout that occurred on a concrete slab-on-grade.

Popout on concrete surfaces results as aggregates absorb water and later expand or swell due to the freezing of absorbed water that creates adequate internal pressure to break off the concrete surface by rupturing the aggregates and the aggregate-paste interfacial bond [4]. Hence, the porosity of aggregates, particularly coarse aggregates, is a vital factor for popouts to occur on concrete surfaces. The alkali-aggregate reactivity is also crucial for popouts to occur [45]. When the cement alkalis react chemically with the silica present in aggregates, the resulting product could cause aggregate breakage and popouts due to expansive forces.

The occurrence of popouts can be minimized by using less porous, strong coarse aggregates and a concrete mix designed with a relatively low water-to-cement ratio. In addition, a proper curing condition should be maintained to achieve better bonding of aggregates and cement paste during the maturity period of the concrete. A good compaction of the freshly placed concrete during construction can also be crucial to reduce popouts on the concrete surfaces. Moreover, an effective penetrating sealer and a suitable opaque or colored film-forming surface coating can be employed to prevent the popout problem from occurring in concrete structures. While applying any surface treatment, a good adhesion between concrete surface and sealer or coating must be achieved to avoid the blistering problem of the treated concrete.

\subsection{Delamination or Mortar Flaking}

Mortar layers flake off due to the excessive sub-surface voids of covercrete or the rusting of reinforcement embedded in concrete [45,47], as shown in Figure 4. Although delamination is not a serious threat to the structural stability of concrete structures, further weathering over time can greatly affect the delaminated areas. Also, mortar flaking diminishes the aesthetic quality of concrete structures. Hence, the mortar flaking areas should be repaired to maintain a good appearance of the concrete structures.

Aggregates tend to settle when fresh concrete is poured and compacted. The settlement of aggregates drives extra mix water and air content to move to the concrete surface. If the finishing procedure starts too early or the concrete surface is sealed before the completion of bleeding (separation of water), the air and water get entrapped under the surface mortar [47]. The entrapped air and water 
create sub-surface voids as concrete begins to harden. These voids form week spots right below the surface layer of concrete, and eventually cause it to delaminate or detach off. The weak zones most often crack and chip away by any strike or rough contact, exposing the delaminated areas. Along with premature finishing, some environmental factors could contribute to delamination. High wind and high temperature promote rapid drying of the concrete surface and thus make it appear as if the surface is ready for finishing (troweling). Delamination can also occur as a result of the rusting of the steel reinforcement used in concrete [45]. The rusting of steel reinforcement results in iron oxides (rusts) that possess a greater volume, therefore they require more space and begin to push on the concrete. As the outer layer is weaker than the interior layer of concrete, the surface layer flakes off when the expansive pressure caused by the rusts overcomes the bond strength of concrete.

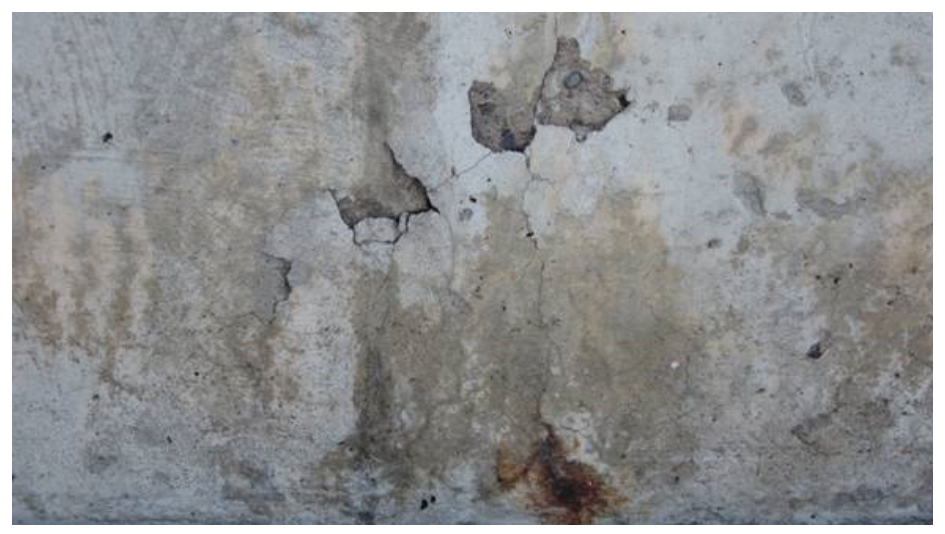

Figure 4. Mortar flaking on the exterior concrete wall of a residential building.

Delamination can be minimized by expelling the air or evaporating the extra water from the concrete surface. Concrete surfaces must be checked to remove hollow spots. The finishing of the concrete surface should be begun after the end of bleeding process. It is strongly recommended to delay the final finishing of concrete surfaces to allow the bleed water and bleed air escape from concrete. In cold-weather concreting, a small dosage of non-chloride set accelerator or heating can be employed to promote more uniform setting of the concrete mix, thus reducing the likelihood of delamination. Appropriate measures should also be taken to counteract rapid evaporative conditions during and after concrete pouring. This is because rapid evaporation can cause plastic shrinkage cracking on concrete surfaces that may aggravate delamination. Furthermore, delamination can be reduced by using the corrosion-resistant concrete reinforcement or protecting the steel reinforcement in concrete.

\subsection{Drying Shrinkage Cracking}

Concrete undergoes volume loss or shrinkage when the excess moisture from the concrete starts to evaporate [45]. Drying shrinkage can cause cracks on concrete surface, as shown in Figure 5, when the shrinking of concrete elements is restrained [4,48]. The extent of shrinkage cracks depends on the rate of drying. Shrinkage cracks can occur in any location of the concrete and there is no special pattern for cracking. However, these cracks generally occur at right angles to the restraints.

A simple way to reduce drying shrinkage cracking is to make sure that sufficient water is available during the curing period to prevent the concrete from being over dried. Drying shrinkage can also be minimized by reducing the amount of water in the concrete mix. Water-reducing admixtures can be used to decrease the water content of concrete mixes while maintaining an adequate fluidity in the freshly mixed concrete. Moreover, internal curing of concrete by employing water reservoirs such as pre-wetted aggregates can be helpful in reducing the drying shrinkage of concrete [49]. Shrinkage-compensating mineral or chemical admixtures can also be used in the concrete mix to reduce drying shrinkage cracking. A surface coating can be applied to fill drying shrinkage cracks 
and coat the entire concrete surface for improving the performance of the concrete structures in field conditions.

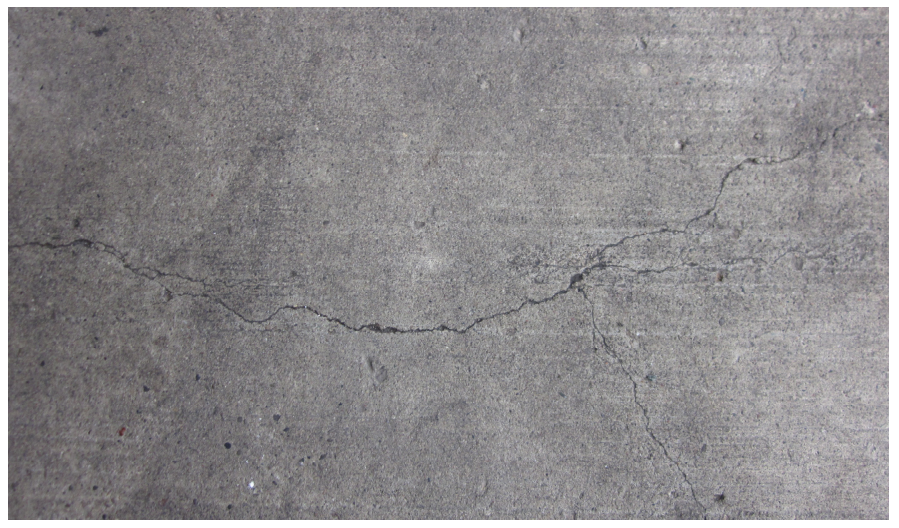

Figure 5. Drying shrinkage cracking on the concrete slab of a pedestrian bridge.

\subsection{Map Cracking or Crazing}

Map cracking or crazing typically occurs when the surface of poured concrete dries and contracts. The absence of proper curing process is a key factor for map cracking due to excessive water loss from the concrete surface [50]. When curing is not employed properly, particularly at the early age of concrete, it loses surface moisture too quickly, thus causing shrinkage on the surface. The strength of the concrete may not be adequate to resist its volume contraction occurring during the setting period. As a result, inter-connected cracks, as shown in Figure 6, appear on the concrete surface. The crack width is relatively small in the case of map cracking.

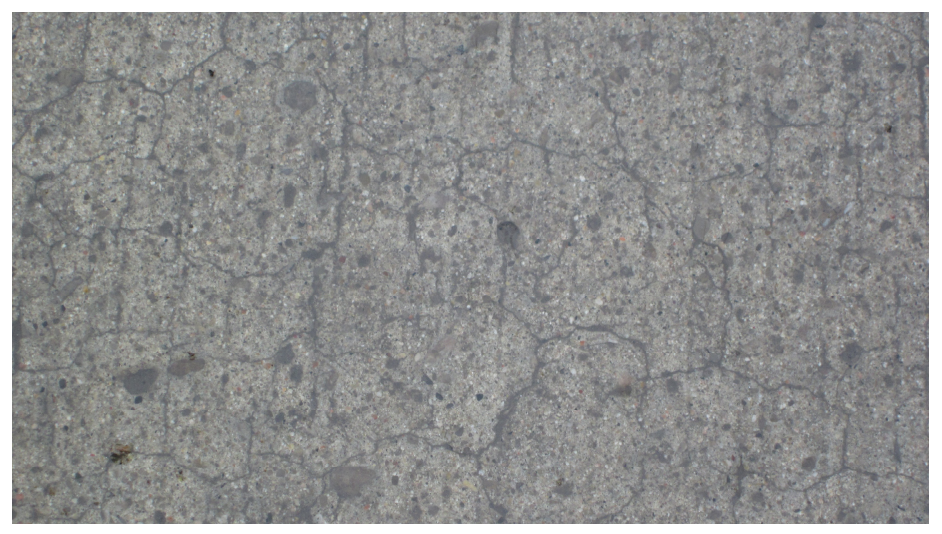

Figure 6. Map cracking or crazing on the concrete walkway of a subway station.

The main factor that influences the map cracking of concrete is water-to-cement ratio. Environmental factors such as temperature, sunlight, humidity, and wind conditions can aggravate map cracking $[45,50]$. This type of cracks can also occur as the result of alkali-carbonate reaction in concrete [4]. Avoiding the use of excess water in the concrete mix and curing the poured concrete properly may minimize the occurrence of map cracking. It can also be minimized by using a low-shrinkage concrete mix. A concrete surface having map cracks can be treated with a surface coating to improve its performance in field conditions. 


\subsection{Corrosion-Induced Cracking}

Corrosion of steel reinforcement in concrete structures is a global problem. This problem is worsened in the presence of chloride-based de-icing or anti-icing salts. Many studies reported that the penetration of chlorides accelerates the corrosion of steel reinforcement in concrete structures [51-57]. Besides, Kozikowski et al. [14] reported that $\mathrm{MgCl}_{2}$ solution forms brucite $\left[\mathrm{Mg}(\mathrm{OH})_{2}\right]$, which hastens the corrosion of steel reinforcement by reducing the $\mathrm{pH}$ of the pore water of concrete. Carbonation also intensifies the corrosion of steel reinforcement with a reduction in the $\mathrm{pH}$ of concrete pore water $[4,58]$. The most common outcome of the reinforcement corrosion is cracking in the concrete, as shown in Figure 7.

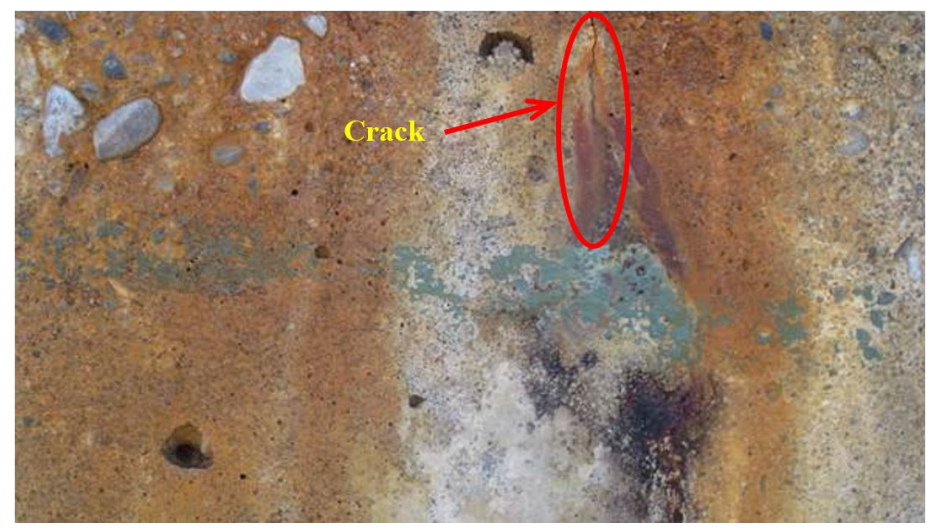

Figure 7. Corrosion-induced cracking on the retaining wall of a retail store parking lot.

Concrete requires water or moisture as an electrolyte for corrosion to occur through electro-chemical reactions [59]. Also, chloride ions gain access to the concrete when chloride-laden water infiltrates the concrete surface. Chlorides breach the protective oxide (passive) film of steel reinforcement and thus can accelerate the corrosion process in concrete [53]. The cracking occurs when the corrosion products develop the expansive force exceeding the tensile strength of concrete.

The corrosion of steel reinforcement can be significantly decreased by preventing the infiltration of water into concrete. This can be achieved by means of surface treatments. Sealer and coating systems can be used to substantially reduce the penetration of water and water-laden chlorides into concrete.

\subsection{Stains}

Stains can appear on concrete surfaces originating from many sources. It could be caused by the aggregates containing iron oxide [60]. Organic matters such as tree leaves may cause some stains on concrete surfaces upon rotting. Stains can also occur from the corrosion of steel reinforcement and the exposure of concrete surfaces to de-icing salts, as shown in Figure 8. The corrosion products (rusts) migrate from the steel re-bar sites to the vicinity of the concrete surface [61]. Rust stains occur when the corrosion products leach out of the concrete surface and migrate within the same element or to another element. The salt stain occurs due to the chemical reaction of de-icing salts with concrete [62]. The deposition of solid salts into the surface pores of concrete can also cause this type of stain.

Stains usually do not pose any critical structural problem in concrete structures. However, they degrade the appearance or aesthetic quality of concrete. Hence, concrete structures having stains may lose their attraction in the built environment. A good aesthetic appearance can be regained by using a colored film-forming coating on the concrete surface after neutralizing or washing off the stained areas of concrete structures. 


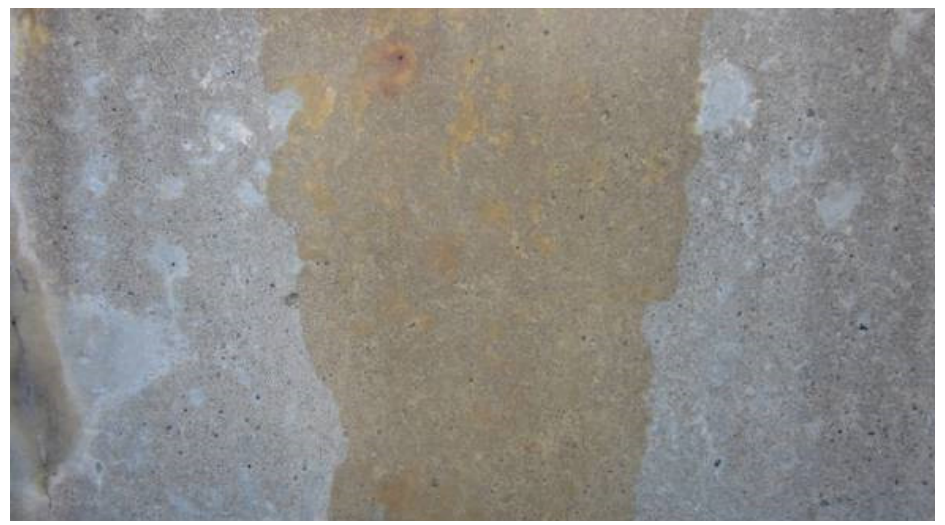

Figure 8. Rust and salt stains on the concrete sidewalk of a low-rise commercial building.

\subsection{Discoloration}

Discoloration is a color difference on concrete surfaces. It can occur due to the presence of streaks on the concrete surface, as shown in Figure 9. Discoloration can be caused by many factors. However, the common reasons of the discoloration are the inconsistent use of materials, the incorporation of inappropriate admixtures, the variations in water-to-cement ratio, inadequate curing, and improper finishing [45,63]. The discoloration of cast-in-place concrete walls or slabs generally occurs due to the changes in the concrete mix composition and construction practices [63]. This problem can be avoided by simply having reasonably thorough and fast work skills. The discoloration problem existing on concrete surfaces can be resolved by using a colored film-forming coating on the concrete surface.

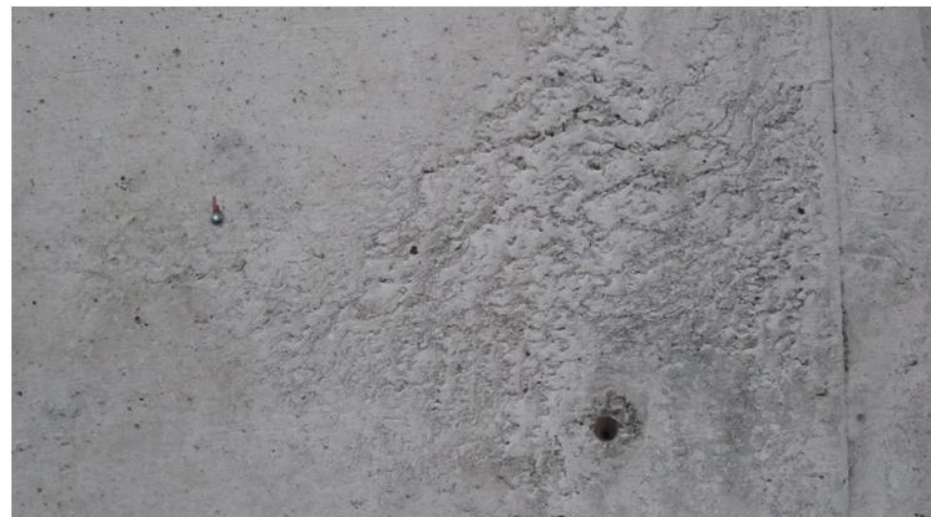

Figure 9. Discoloration on the interior concrete wall of an institutional building.

\subsection{Moss and Mold Growths}

Moss growth is a common problem on concrete surfaces that remain shaded and fairly damp or moist throughout the day. Mosses depend on moisture to reproduce and grow best on porous surfaces like that of concrete [64]. Mosses grown on concrete surface are usually yellow, green or greenish brown in color. The presence of mosses diminishes the aesthetic appeal of concrete surface. They make the concrete surface old and dirty, as obvious from Figure 10. Also, mosses can make the concrete surface quite slippery and pose safety problems by growing on the pedestrianized paths. The moss growth on new concrete surfaces can be avoided using water-repelling coatings. The mosses existing on old concrete surfaces can be removed by chemical treatment. A surface treatment in the form of a coating may then be applied to avoid further moss growth. 


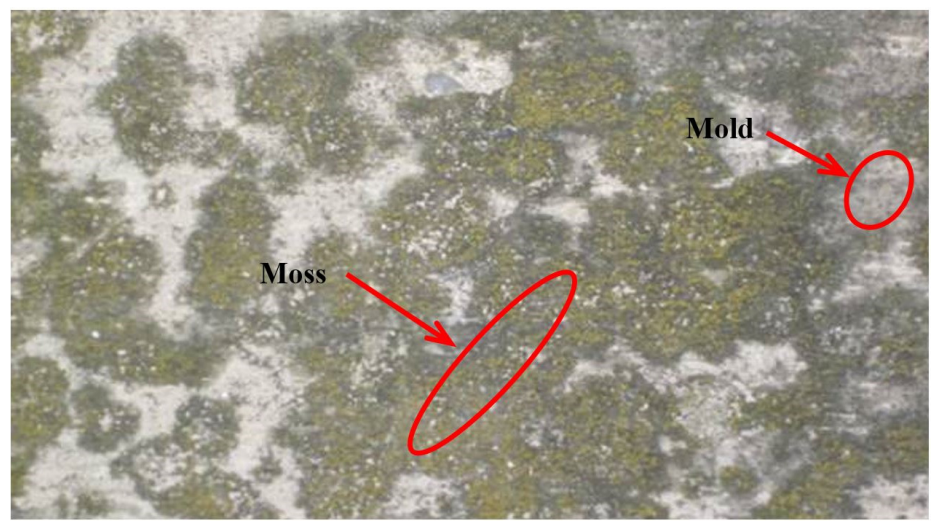

Figure 10. Mold and moss growths on the exposed surface of a concrete retaining wall.

Mold is a type of fungus that consists of multicellular filaments. It can grow on damp or moist concrete surfaces, as evident from Figure 10. Molds require moisture to grow. They often cause black stains on concrete surfaces. Molds can also cause white, orange, green or pink/purple stains [65]. The exposure to molds can cause allergic reactions. They degrade indoor living environments by growing on interior concrete surfaces. The mold growth on new concrete surfaces can be minimized by using a surface coating. In the case of old concrete surfaces, the existing molds can be cleaned chemically. The chemical may be applied with a brush; then, the surface should be scrubbed and water-rinsed. Pressure washing can also be used to remove the molds from the large areas of concrete surface. The surface treatment of the cleaned and washed concrete with a coating can stop further mold growth directly on the concrete faces.

\section{Protective Sealer and Coating Systems}

Sealer or coating systems are applied on concrete as surface treatments to protect concrete structures from different forms of damage. They provide protection to concrete by impeding the ingress of water and many detrimental chemicals such as de-icing or anti-icing chloride salts, sulfate and chloride salts from seawater, sulfate ions from soil, and deleterious gases (for example, carbon dioxide) from atmospheric environment [62]. Different types of sealer and coating are presently used for the protection of concrete $[23,34,35,66]$. Sealers and coatings are typically applied to concrete bridge and building components to protect them from environmental attacks accelerated by freezing and thawing, wetting and drying, and abrasion. They are intended to reduce different forms of concrete damage, such as surface scaling, spalling, popout, delamination, and cracking [34-37]. Furthermore, sealers and coatings are used to decrease or eliminate the chemical attack and corrosion damage caused by de-icing or anti-icing corrosive chemicals [34,38].

\subsection{Types of Sealer and Coating Systems}

The following sealer and coating materials are generally used to protect concrete surfaces from the damage encountered in field conditions. This classification is based on the protection mechanism of the sealer and coating systems $[66,67]$.

- Penetrating sealers: low-viscosity materials, which are "flood coated" to achieve typically 1-3 mm penetration into concrete. These are mostly silane/siloxane or silicate based materials. Silane/siloxane based sealers produce a hydrophobic lining on the pore-wall of capillary pores to repel water and thus reduce the water ingress into concrete. In contrast, silicate based penetrating sealers can react chemically with calcium hydroxide (also known as portlandite), a by-product of the cement hydration in concrete, to produce additional C-S-H (calcium silicate hydrate) gel, which makes the concrete denser and potentially stronger by filling cracks and capillary pores [66]. 
- Surface sealers: medium-viscosity/low-solid materials, which form a thin film on the concrete surface; the thin film does not infiltrate the capillary pores present in concrete. These sealers must adhere to the concrete surface when they are applied to form a thin film. They are mainly epoxy, urethane or methyl methacrylate based materials.

- Barrier or surface coatings: high-viscosity/high-solid materials, which form a relatively thick film on concrete surfaces; this thick film does not infiltrate the capillary pores of concrete rather creates a protective barrier on concrete surfaces. These coatings must possess good adhesion with the concrete substrates for optimum performance in field conditions. They are mostly acrylic, epoxy or urethane based polymeric materials. These coatings can also be bituminous or cementitious materials.

- Impregnating polymers: ultra-low-viscosity materials, which are applied by special drying and vacuum techniques to ensure the deep penetration into concrete; they block the capillary pores in concrete. These are mainly styrene, acrylonitrile, or high-molecular-weight methacrylate based materials.

The barrier or surface coating systems, as mentioned above, are further classified as follows, based on the major component materials present in the coating composition [68].

- Bituminous coatings: these coatings can be hot-applied or cold-applied; the cold application of bituminous materials employs asphalt emulsions as coating agents. They are asphalt, tar, or pitch based materials. These coatings are effective when the stresses (mostly in the forms of air pressure and hydrostatic pressure) on the surface are insignificant. In the cases of significant stresses on the concrete surface, several layers of bituminous coating are applied alternately with mineral or glass fibre felt. Moreover, the compatibility between concrete substrate and coating should be considered. Regarding the emulsified bituminous coatings, since both the aggregate and coating material have electrically charged surfaces, the compatibility between them are very important for optimum adhesion [69,70]. An example of an applied bituminous coating is shown in Figure 11.

- Cementitious coatings: these are high-density, high-strength waterproofing coatings; they include carefully graded solid materials (generally silica-based particles) in their composition, along with cementitious materials and liquid organic or inorganic chemicals. The dry components are mixed uniformly with the liquid chemicals to prepare these coatings. These coatings offer high durability for concrete structures. An example of an applied cementitious coating is shown in Figure 12.

- Polymeric coatings: These coatings are available with different fillers and texturing aggregates; they offer a variety of colors and attractive finishes for concrete structures. Also, these coatings offer good durability when they are applied with an adequate film thickness. They are usually acrylic, epoxy, urethane, or methyl methacrylate based materials. An example of an applied polymeric coating is shown in Figure 13.

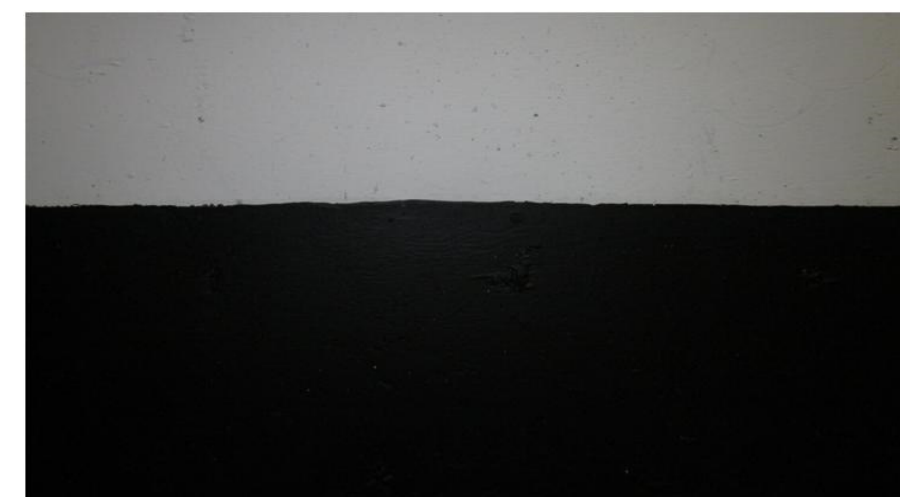

Figure 11. Bituminous coating applied on the concrete basement wall of a high-rise building. 


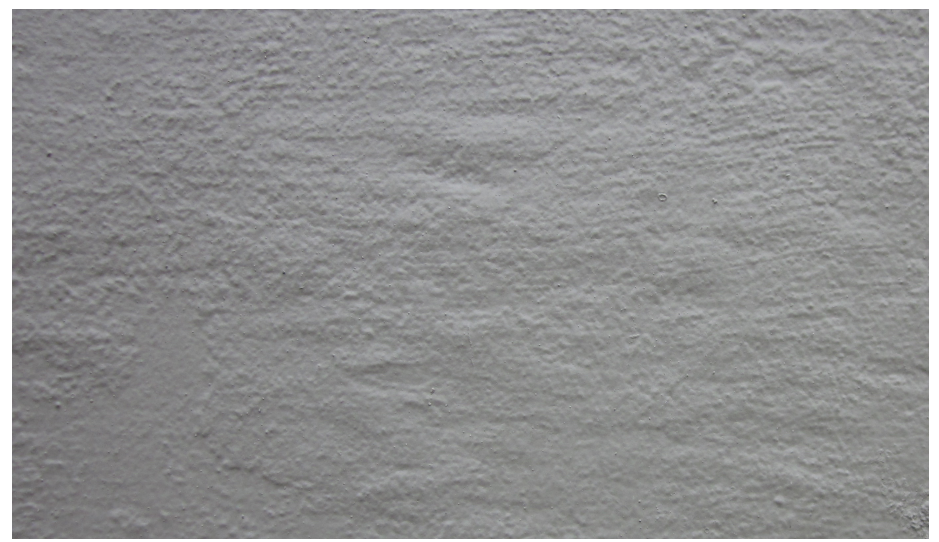

Figure 12. Cementitious coating applied on the concrete staircase wall of a parking structure.

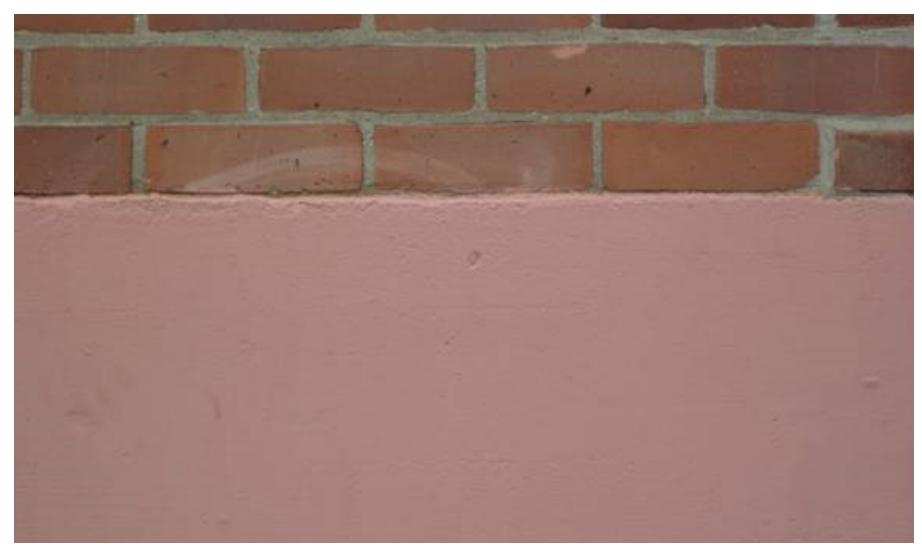

Figure 13. Colored polymeric coating applied on the foundation wall of an institutional building.

\subsection{Selection of Sealer and Coating Systems}

The selection and performance of a sealer or coating product depend on its quality, type and/or properties, the exposure conditions both during application and when in service, the condition of the underlying concrete (smoothness, roughness, moisture level, etc.), the efficiency of the techniques used to prepare the substrate, and the way in which it is applied. The selected sealers or coatings should have (a) good ability to seal or coat new, old, or previously sealed/coated surfaces; (b) excellent ability to reduce or eliminate the ingress of moisture; (c) excellent ability to transmit the moisture vapor from concrete (breathability); (d) good salt scaling resistance; (e) good chemical resistance; (f) good resistance to ultra-violet (UV) rays; (g) excellent penetration into the concrete surface; (h) good skid resistance; (i) low toxicity; and (j) adequate volatility for their effective use [39]. The specific factors listed in Table 1 should be considered during the selection of sealer or coating products for application on concrete structures. These factors will influence the performance of sealers or coatings in field conditions. 
Table 1. Factors to be considered during the selection of concrete sealers or coatings (adapted from $[30,71])$.

\begin{tabular}{ll}
\hline \multicolumn{1}{c}{ Specific Factor } & \multicolumn{1}{c}{ Consideration } \\
\hline $\begin{array}{l}\text { Type of concrete substrate and } \\
\text { its surface condition }\end{array}$ & $\begin{array}{l}\text { Old or new concrete; any prior treatment, roughness, and contamination of } \\
\text { concrete surface }\end{array}$ \\
\hline Nature of exposure & $\begin{array}{l}\text { Atmospheric, marine, or buried environment; presence of moisture, } \\
\text { pollutants, and aggressive chemicals }\end{array}$ \\
\hline Type of concrete protection & $\begin{array}{l}\text { Protection from abrasion, acid or chemical attack, alkali-silica reaction, } \\
\text { alkali-carbonate reaction, carbonation, chloride attack, freezing and } \\
\text { thawing, wetting and drying, salt scaling, sulfate attack, and water ingress }\end{array}$ \\
\hline $\begin{array}{l}\text { Expected durability of sealers } \\
\text { or coatings }\end{array}$ & $\begin{array}{l}\text { Abrasion resistance, adhesion strength, chemical resistance, color retention, } \\
\text { elasticity, film hardness, impact resistance, moisture vapor transmission, } \\
\text { toxicity, UV resistance, and water resistance }\end{array}$ \\
\hline Service condition & $\begin{array}{l}\text { Skid resistance, load-bearing or non-load-bearing condition, and } \\
\text { hydrostatic or air pressure }\end{array}$ \\
\hline $\begin{array}{l}\text { Installation of sealers or } \\
\text { coatings }\end{array}$ & $\begin{array}{l}\text { Methods of installation, surface preparation, influence of temperature, effect } \\
\text { of substrate moisture, and location of site }\end{array}$ \\
\hline Surface treatment costs & $\begin{array}{l}\text { Coverage rate or required number of coats, film thickness, labor cost, } \\
\text { material cost, and maintenance cost }\end{array}$ \\
\hline
\end{tabular}

\subsection{Installtion of Sealer and Coating Systems}

Sealer and coating systems are typically installed using roller, airless spray gun, squeegee, brush or broom [39]. Attanayaka et al. [36] reported that surface flooding is the preferred method for proper application of a penetrating sealer. Ho and Harrison [32] reported that an increased thickness improves the effectiveness of surface coatings, resulting in a greater protection against carbonation. They also stated that a coating installed on a non-prepared concrete surface is more effective than when it is installed on an abrasive-blasted concrete substrate with the same coverage rate. This is because abrasive-blasting typically produces a rough surface profile, which requires an increased coverage rate to achieve a uniform coating thickness. It means the coating thickness decreases in the case of an abrasive-blasted concrete surface for a given coverage rate. However, abrasive-blasting is still useful to attain the required level of coating adhesion and therefore an increased coverage rate is generally recommended when installing a coating on the abrasive-blasted concrete substrate.

Surface preparation is generally required before installing a sealer or coating system on the concrete substrate. In most cases, new concrete should be at least 28 days old, and any contamination, such as form oils and curing compounds that may interfere with the adhesion or penetration of sealer and coating products should be removed [36]. Oil, grease, rubber, and other contaminants should also be removed from old concrete by effective surface preparation techniques for similar reasons, as mentioned above. Furthermore, the removal of the carbonated surface layer of old concrete is recommended, where appropriate, before applying certain types of penetrating sealer to enhance the chemical reactions requiring high alkalinity [37]. Most manufacturers of sealer and coating products recommend abrasive-blasting (sand- or grit-blasting), blast-track (shot-blasting) or high pressure water-blasting techniques for the surface preparation on concrete substrates. This is to ensure good adhesion between the concrete surface and the sealer or coating material. After the completion of the surface preparation, manufacturers may require a damp, saturated surface-dry or dry substrate, depending on their products, prior to the installation of sealer or coating systems.

\subsection{Performance of Sealer and Coating Systems}

Sealer and coating systems can significantly decrease the water ingress into concrete by making concrete pore-walls hydrophobic, blocking capillary pores, forming a uniform physical barrier on concrete surface, or reacting with portlandite present in concrete $[29,66,67]$. Some systems may work via 
double mechanisms having dual-component products in their composition. A decrease in water ingress improves concrete's resistance to freeze-thaw cycles [7] and alkali-aggregate reactions [39]. Porter [27] reported that the surface scaling due to freezing and thawing greatly decreases when sealers or coatings are used on concrete surfaces. Almusallam et al. [22] and Moon et al. [25] observed that surface coatings enhance the freeze-thaw durability and chemical resistance of concrete. Seneviratne et al. [16], Al-Dulaijan et al. [21], Ibrahim et al. [23], and Oshiro and Tanigawa [26] reported that surface coatings substantially decrease the chloride permeability and steel corrosion in the reinforced concrete. Palle and Hopwood II [34] also confirmed that an appropriate sealer or coating system protects the reinforced concrete from corrosion and de-icing chemical attack by preventing chloride penetration.

Moon et al. [25] observed that silicate based inorganic coatings significantly reduce the ingress of carbon dioxide, which also causes the corrosion of steel reinforcement by decreasing the $\mathrm{pH}$ of pore-water in concrete. Ho and Harrison [32] found that the increased film thickness and the roughened concrete surface enhance the protective performance of any coating, as discussed in Section 3.3. McCarter [8] reported that certain surface coatings impede the permeation of water as a liquid into concrete but facilitate the transmission of moisture vapor from concrete through the applied coating. These phenomena help to keep concrete surface dry, thus providing good resistance against many forms of concrete damage. Furthermore, McCarter [8] reported that some surface coatings can extensively increase the resistivity of concrete and improve its resistance to scaling caused by chemical attack. The overall findings from literature survey reveal that sealer or coating systems improve the durability of concrete and thus greatly extend the service life of concrete structures in field conditions. However, the surface coatings installed on concrete substrates can also be damaged over time due to physical and chemical attacks. The performance of treated (sealed or coated) concrete greatly depends on the adhesion of a surface sealer or coating with concrete substrate $[21,26]$. This is particularly crucial to avoid or reduce the delamination or blistering of sealer and coating systems installed on concrete elements or structures.

Sealers and coatings must have adequate adhesion to the concrete substrate, be applied with an adequate thickness, and provide an acceptable level of impermeability to the ingress of chloride-laden water to ensure effective performance of the treated concrete against adverse environments $[17,18,62,72]$. They must be able to resist the stresses that tend to force the water through the sealer and coating systems. These stresses are (a) the gravity that forces water through horizontal concrete surfaces (for example, building roof and bridge deck); (b) the hydrostatic pressure on one side of horizontal or vertical concrete elements (for example, slab-on-grade, basement wall, and foundation wall of buildings); and (c) an air pressure difference on horizontal or vertical concrete elements (for example, roof slab and exterior wall of buildings). If the sealer and coating systems fail to resist the aforementioned stresses and possess inadequate adhesion, the delamination of the sealer or coating system, as shown in Figure 14, will occur. A thick coating and a rough surface profile, as discussed in Section 3.3, contribute to provide a greater adhesion and a higher resistance to the aforementioned disruptive forces or stresses.

The performance of sealer and coating systems also largely depends on their capability of transmitting the moisture vapor from the interior of concrete. Both sealers and coatings should have an acceptable level of "breathability" when it is desirable for the moisture to transmit from the concrete through the treated surface [28]. Otherwise, delamination or blistering may occur on the sealer and coating systems. Various performance criteria that have been established for the use of sealer and coating systems are given in Tables 2 and 3. These criteria are used to evaluate the performance of concrete sealers and coatings in field conditions with respect to their durability and durability-related properties. 


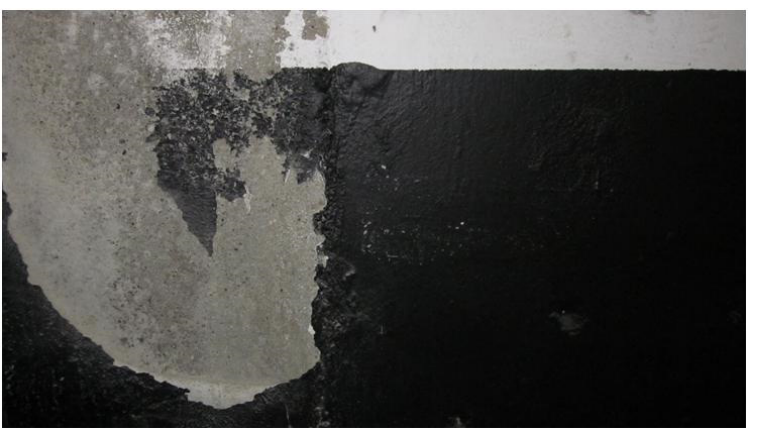

(a)

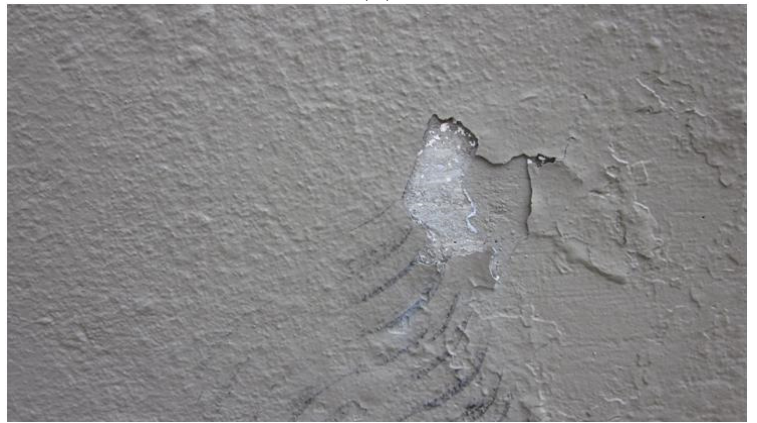

(b)

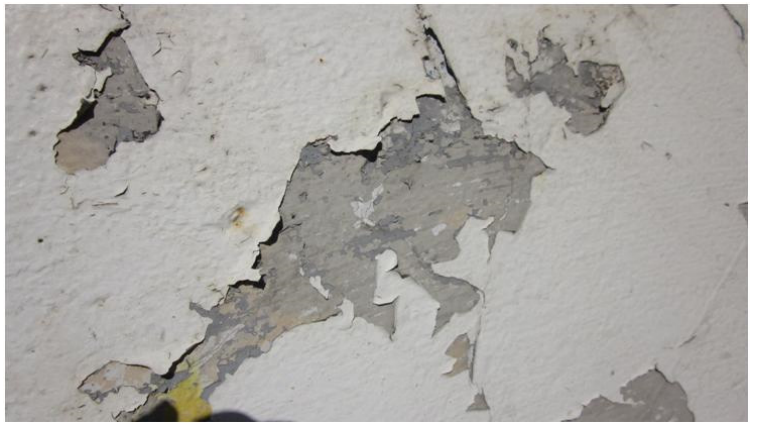

(c)

Figure 14. Delamination of (a) bituminous, (b) cementitious, and (c) polymeric coatings.

Table 2. Various performance criteria for concrete sealers or coatings [35,37].

\begin{tabular}{lll}
\hline \multicolumn{1}{c}{ Method } & \multicolumn{1}{c}{ Property } & \multicolumn{1}{c}{ Performance Criteria } \\
\hline $\begin{array}{l}\text { Freeze-thaw / salt scaling resistance test } \\
\text { as per ASTM C672/C672M [73] }\end{array}$ & $\begin{array}{l}\text { Scaling resistance of concrete } \\
\text { exposed to de-icing salts under } \\
\text { freezing and thawing cycles }\end{array}$ & $\begin{array}{l}\text { No visible damage (rating "0") after } \\
50 \text { freeze-thaw cycles, rating “0”-no } \\
\text { scaling after } 100 \text { cycles, and rating of } \\
1 \text { lower than that of untreated concrete } \\
\text { surface in the case of scaling }\end{array}$ \\
\hline $\begin{array}{l}\text { Water absorption test based on cold } \\
\text { water saturation technique given in } \\
\text { ASTM C642 [74] }\end{array}$ & $\begin{array}{l}\text { Water absorption (wt. \%) as an } \\
\text { indicator of concrete durability }\end{array}$ & $\begin{array}{l}\text { Maximum } 1 \% \text { after } 48 \mathrm{~h} \text { and maximum } \\
2 \% \text { after } 50 \text { days }\end{array}$ \\
\hline $\begin{array}{l}\text { Chloride ion penetration test based on } \\
\text { ponding technique given in AASHTO } \\
\text { T259 [75] }\end{array}$ & $\begin{array}{l}\text { Penetrated chloride value as an } \\
\text { indicator of the corrosion } \\
\text { resistance of concrete }\end{array}$ & $\begin{array}{l}0.451-0.593 \mathrm{~kg} / \mathrm{m}^{3} \text { at } 12.7-25.4 \mathrm{~mm} \\
(0.76-1.0 \mathrm{pcy} \text { at } 0.50-1.0 \text { in.) depth after } \\
90 \text { days of ponding }\end{array}$ \\
\hline $\begin{array}{l}\text { Accelerated weathering test as per } \\
\text { ASTM D822/D82M [76] }\end{array}$ & Weathering resistance of concrete & Slight color change on concrete surface \\
\hline $\begin{array}{l}\text { Salt spray resistance test according to } \\
\text { ASTM B117 [77] }\end{array}$ & Adhesion or bond strength & $\begin{array}{l}\text { No loss of adhesion after 300 } \\
\text { freeze-thaw cycles }\end{array}$ \\
\hline $\begin{array}{l}\text { Electrical resistance test by Two-pin } \\
\text { mode soil resistance meter }\end{array}$ & Electrical resistance of concrete & $>200-400 \mathrm{k} \Omega$ \\
\hline
\end{tabular}


Table 3. Waterproofing performance criteria for concrete sealers or coatings $[78,79]$.

\begin{tabular}{lccc}
\hline \multicolumn{1}{c}{ Sealer or Coating Type } & \multicolumn{2}{c}{$\begin{array}{c}\text { Minimum Waterproofing Performance * (as } \\
\text { Compared to Unsealed or Uncoated Specimens) }\end{array}$} & $\begin{array}{c}\text { Minimum Vapor Transmission } \\
\text { (as Compared to Unsealed or } \\
\text { Uncoated Specimens) }\end{array}$ \\
\cline { 2 - 3 } & Before Abrasion & After Abrasion & - \\
\hline $\begin{array}{l}\text { Penetrating sealer for concrete surfaces } \\
\text { with a relative moisture content } \leq 55 \% \\
\text { (Type 1a) }\end{array}$ & $82.5 \%$ & $75.0 \%$ & $70.0 \%$ \\
\hline $\begin{array}{l}\text { Penetrating sealer for concrete surfaces } \\
\text { with a relative moisture content } \leq 70 \% \\
\text { (Type 1b) }\end{array}$ & - & $86.0 \%$ & \\
\hline $\begin{array}{l}\text { High performance penetrating sealer } \\
\text { for concrete surfaces with a relative } \\
\text { moisture content } \leq 80 \% \text { (Type 1c) }\end{array}$ & - & $85.0 \%$ & \\
\hline $\begin{array}{l}\text { Clear film-forming one-component } \\
\text { sealer or coating for concrete surfaces } \\
\text { with a relative moisture content } \leq 70 \% \\
\text { (Type 2a) }\end{array}$ & $82.5 \%$ & N/A & $35.0 \%$ \\
\hline $\begin{array}{l}\text { Clear film-forming two-component } \\
\text { sealer or coating for concrete surfaces } \\
\text { with a relative moisture content } \leq 70 \% \\
\text { (Type 2b) }\end{array}$ & $90.0 \%$ & N/A & \\
\hline $\begin{array}{l}\text { Colored film-forming sealer or surface } \\
\text { coating for concrete surfaces (Type 3) }\end{array}$ & $75.0 \%$ & N/A & $20.0 \%$ \\
\hline
\end{tabular}

\subsection{Evaluation of Sealer and Coating Systems}

The following test methods can be used to evaluate the performance of sealer and coating systems installed on concrete substrates.

- AASHTO T161: Standard method of test for resistance of concrete to rapid freezing and thawing [80], ASTM C666/C666M: Standard test method for resistance of concrete to rapid freezing and thawing [81], and ASTM D2243: Standard test method for freeze-thaw resistance of water-borne coatings [82]. These test methods can be used for treated and untreated concretes to determine their freeze-thaw resistance.

- AASHTO T259: Standard method of test for resistance of concrete to chloride ion penetration [75], AASHTO T260: Sampling and testing for chloride ion in concrete and concrete raw materials [83], AASHTO T277: Standard method of test for electrical indication of concrete's ability to resist chloride ion penetration [84], ASTM C1152/C1152M: Standard test method for acid-soluble chloride in mortar and concrete [85], ASTM C1202: Standard test method for electrical indication of concrete's ability to resist chloride ion penetration [86], and ASTM C1543: Standard test method for determining the penetration of chloride ion into concrete by ponding [87]. These test methods can be used for treated and untreated concretes to determine their chloride ion penetration resistance.

- $\quad$ ASTM D822/D822M: Standard practice for filtered open-flame carbon-arc exposures of paint and related coatings [76] and ASTM D4587: Standard practice for fluorescent UV-condensation exposures of paint and related coating [88]. These practices can be used in the evaluation of the accelerated weathering resistance of concrete sealers or coatings.

- ASTM C672/C672M: Standard test method for scaling resistance of concrete surfaces exposed to de-icing chemicals [73]. This test, commonly known as salt scaling test, is carried out to determine the salt scaling resistance of treated and untreated concretes.

- $\quad$ ASTM B117: Standard practice for operating salt spray (fog) apparatus [77]. This practice can be used in determining the salt spray resistance of untreated and treated concretes.

- ASTM C642: Standard test method for density, absorption and voids in hardened concrete [74], ASTM D4585/D4585M: Standard practice for testing water resistance of coatings using controlled 
condensation [89], and ASTM D6489: Standard test method for determining the water absorption of hardened concrete treated with a water-repellent coating [90]. The test methods given in these ASTM standards can be used to determine the water penetration resistance of treated and untreated concretes.

- $\quad$ ASTM D1653: Standard test methods for water vapor transmission of organic coating films [91] and ASTM E96/E96M: Standard test methods for water vapor transmission of materials [92]. These test methods are used to determine the water vapor transmission capacity of sealer or coating systems installed on concrete substrates.

- ASTM D3273: Standard test method for resistance to growth of mold on the surface of interior coating in an environmental chamber [93] and ASTM D3274: Standard test method for evaluating degree of surface disfigurement of paint films by microbial (fungal and algal) growth or soil and dirt accumulation [94]. These tests can be performed to determine the resistance of treated and untreated concretes to microbial growth such as mold and moss growths.

- $\quad$ ASTM D4541: Standard test method for pull-off strength of coatings using portable adhesion testers [95]. This test is conducted to examine the adhesion or bond strength of coatings installed on concrete substrates.

- $\quad$ ASTM D2794: Standard test method for resistance of coatings to the effects of rapid deformation (impact) [96]. This test can be used to determine the impact resistance of coatings installed on concrete surfaces.

- $\quad$ ASTM D1654: Standard test method for evaluation of painted or coated specimens subjected to corrosive environments [97]. This test can be carried out to evaluate the basic corrosion performance (the blistering and loss of adhesion associated with corrosion) of coatings installed on concrete substrates.

\section{Recommendations for Improved Performance of Sealer and Coating Systems}

- Consider the following characteristics while selecting sealer or coating products for installation on concrete surface: (a) the ability to seal or coat new, old, or previously sealed/coated surface; (b) the capability to reduce or eliminate the ingress of moisture and chlorides; (c) the ability to transmit the moisture vapor from concrete (breathability); (d) salt scaling resistance; (e) chemical resistance; (f) the resistance to degradation from UV rays; (g) the penetration into concrete surface, and (h) the ability to provide good skid resistance.

- Before applying sealer or coating products on concrete substrates, (a) ensure that the new concrete is at least 28 days old; (b) remove contaminants (form oil, curing compound, grease, rubber, etc.) from concrete surfaces; (c) replace the defective surface layer of concrete with high quality mortar or concrete; (d) prepare a rough surface profile by abrasive-blasting, shot-blasting, or high pressure water-blasting as recommended by the manufacture for good adhesion of the coating and better penetration of the penetrating sealer through open surface pores; (e) repair cracks existing on concrete surfaces according to industry standards; ( $\mathrm{f}$ ) condition the prepared concrete substrate in accordance with the manufacture's requirement; (g) use spray gun, roller, squeegee, brush, or broom as required by the manufacturer to apply the coating with the recommended coverage rate; and $(\mathrm{h})$ consider a surface flooding or spraying technique to apply the penetrating sealer with the coverage rate as recommended by the manufacturer.

- Avoid using the more aggressive de-icing or anti-icing chemicals if possible; when applying the solution of de-icing or anti-icing chemicals, use the lowest possible concentration to lessen the degree of chemical attacks.

- Before installing sealer or coating systems on concrete substrates, examine (a) adhesion or bond strength; (b) scaling resistance to freeze-thaw and wet-dry cycles in the presence of de-icing or anti-icing chemicals; (c) water absorption; (d) moisture vapor transmission; and (e) chloride ion penetration resistance. 


\section{Conclusions}

This study was carried out to identify different forms of concrete damage in field conditions and how the concrete damage can be minimized by using protective sealer and coating systems. The type and selection, installation, performance, and evaluation of sealer or coating systems have been discussed. Also, some recommendations regarding the applications of sealer and coating systems on concrete structures are given. From the present study, the following conclusions are drawn:

- Different forms of concrete damage, such as scaling, popout, map cracking, delamination, corrosion-induced cracking, spalling, drying shrinkage cracking, mold and moss growths, rust and salt stains, and discoloration occur in field conditions, depending on the nature and degree of exposure.

- Freezing and thawing cycles cause scaling, popout, delamination, and internal frost damage in concrete; these phenomena are intensified when water penetrates the concrete surface and remains in the pore structure of concrete.

- De-icing or anti-icing chemicals cause significant damage to concrete surfaces in the form of scaling and salt stains; they also aggravate the corrosion of steel reinforcement, resulting in cracking, spalling and rust stains in concrete.

- Concrete damage is considerably reduced when sealers or coatings are applied on concrete surfaces because they substantially decrease the infiltration of deleterious agents such as chlorides and carbon dioxide into concrete.

- Sealer and coating systems significantly lessen the ingress of water, which is essential for many damage mechanisms; in addition, many sealer and coating products enhance the transmission of water vapor from concrete upon drying and thus minimize the damaging effect of freeze-thaw cycles.

- Sealer and coating products perform better when they are applied on the concrete substrate with an adequate film thickness and possess good adhesion with concrete surfaces.

- Proper selection of products, appropriate surface preparation, use of less aggressive de-icing or anti-icing chemicals, and accurate evaluation before application will help to improve the performance of concrete sealer and coating systems in field conditions.

Acknowledgments: The author is grateful to Angelo Del Zotto School of Construction Management, George Brown College, for the support to perform this study. The author is also thankful to the library of George Brown College for the electronic resources used in literature review.

Conflicts of Interest: The author declares no conflict of interest.

\section{References}

1. Wittmann, F.H.; Zhao, T.; Zhang, P.; Jiang, F. Service life of reinforced concrete structures under combined mechanical and environmental loads. In 2nd International Symposium on Service Life Design for Infrastructure (Pro070); van Breugel, K., Ye, G., Yuan, Y., Eds.; RILEM Publications SARL: Paris, France, 2010; pp. 91-98.

2. Bonić, Z.; Curčić, G.T.; Davidović, N.; Savić, J. Damage of concrete and reinforcement of reinforced-concrete foundations caused by environmental effects. Procedia Eng. 2015, 117, 411-418. [CrossRef]

3. Berkowski, P.; Kosior-Kazberuk, M. Material and structural destruction of concrete elements in the industrial environment. Procedia Eng. 2017, 172, 96-103. [CrossRef]

4. Types and Causes of Concrete Deterioration; Concrete Information, PCA R\&D Serial No. 2617; Portland Cement Association (PCA): Skokie, IL, USA, 2002; p. 16.

5. Pan, X.; Shi, Z.; Shi, C.; Ling, T.-C.; Li, N. A review on surface treatment for concrete-Part 2: Performance. Constr. Build. Mater. 2017, 133, 81-90. [CrossRef]

6. Pan, X.; Shi, Z.; Shi, C.; Ling, T.-C.; Li, N. A review on concrete surface treatment Part I: Types and mechanisms. Constr. Build. Mater. 2017, 132, 578-590. [CrossRef]

7. Litvan, G.G. The effect of sealers on the freeze-thaw resistance of mortar. Cem. Concr. Res. 1992, 22, 1141-1147. [CrossRef] 
8. McCarter, W.J. Assessing the protective qualities of treated and untreated concrete surfaces under cyclic wetting and drying. Build. Environ. 1996, 31, 551-556. [CrossRef]

9. Scherer, G.W.; Valenza, J.J. Mechanisms of frost damage. In Materials Science of Concrete; American Ceramic Society: Westerville, OH, USA, 2005; Volume 3, pp. 209-246.

10. Darwin, D.; Browning, J.; Gong, L.; Hughes, S.R. Effects of Deicers on Concrete Deterioration. In A Report on Research Sponsored by the Structural Engineering and Materials Laboratory; University of Kansas (SL Report 07-3); The University of Kansas Center for Research, Inc.: Lawrence, KS, USA, 2007.

11. Darwin, D.; Browning, J.; Gong, L.; Hughes, S.R. Effects of deicers on concrete deterioration. ACI Mater. J. 2008, 105, 622-627.

12. Hooton, R.D.; Julio-Betancourt, G.A. Investigation of the Effects of Various Deicing Chemicals, Curing Methods, and Concrete Placement on Salt Scaling Resistance of Concrete Surface; Final Report to Ready Mixed Concrete Association of Ontario; University of Toronto: Toronto, ON, Canada, 2005.

13. Julio-Betancourt, G.A. Effect of De-icer and Anti-icer Chemicals on the Durability, Microstructure, and Properties of Cement-Based Materials. Ph.D. Thesis, University of Toronto, Toronto, ON, Canada, 2009.

14. Kozikowski, R.L.; Taylor, P.C.; Pyc, W.A. Evaluation of Potential Concrete Deterioration Related to Magnesium Chloride $\left(\mathrm{MgCl}_{2}\right)$ Deicing Salts; PCA R\&D Serial No. 2770; Portland Cement Association (PCA): Skokie, IL, USA, 2007.

15. Sutter, L.L.; Peterson, K.; Julio-Betancourt, G.; Hooton, D.; van dam, T.J.; Smith, K. The Deleterious Chemical Effects of Concentrated Deicing Solutions on Portland Cement Concrete. Study SD 2002-01 Implementation Guide; Michigan Tech Transportation Institute: Houghton, MI, USA, 2008.

16. Seneviratne, A.M.G.; Sergi, G.; Page, C.L. Performance characteristics of surface coatings applied to concrete for control of reinforcement corrosion. Constr. Build. Mater. 2000, 14, 55-59. [CrossRef]

17. Soudki, K.A.; Safiuddin, M.D.; Jeffs, P.; MacDonald, G.; Kroker, M. Chloride penetration resistance of concrete sealer and coating systems. J. Civil Eng. Manag. 2015, 21, 492-502. [CrossRef]

18. Soudki, K.A.; Jeffs, P.; Safiuddin, M.D. Chloride Penetration Resistance of Concrete Coating Systems on Region of Waterloo Bridges; Final Research Report Submitted to the Region of Waterloo; Department of Civil and Environmental Engineering, Faculty of Engineering, University of Waterloo: Waterloo, ON, Canada, 2012.

19. Dang, Y.; Xie, N.; Kessel, A.; McVey, E.; Pace, A.; Shi, X. Accelerated laboratory evaluation of surface treatments for protecting concrete bridge decks from salt scaling. Constr. Build. Mater. 2014, 55, 128-135. [CrossRef]

20. Pigeon, M.; Talbot, C.; Marchand, J.; Hornain, H. Surface microstructure and scaling resistance of concrete. Cem. Concr. Res. 1996, 26, 1555-1566. [CrossRef]

21. Al-Dulaijan, S.U.; Maslehuddin, M.; Al-Zahrani, M.M.; Al-Juraifani, E.A.; Al-Idi, S.H.; Al-Mehthel, M. Performance evaluation of cement-based surface coatings. In Repair, Rehabilitation, and Maintenance of Concrete Structures, and Innovations in Design and Construction, Proceedings of the ACI Fourth International Conference (ACI SP-193), Seoul, Korea, 19-22 September 2000; American Concrete Institute: Detroit, MI, USA, 2000; pp. 321-335.

22. Almusallam, A.A.; Khan, F.M.; Dulaijan, S.U.; Al-Amoudi, O.S.B. Effectiveness of surface coatings in improving concrete durability. Cem. Concr. Compos. 2003, 25, 473-481. [CrossRef]

23. Ibrahim, M.; Al-Gahtani, A.S.; Maslehuddin, M.; Dakhil, F.H. Use of surface treatment materials to improve concrete durability. ASCE J. Mater. Civ. Eng. 1999, 11, 36-40. [CrossRef]

24. Jones, M.R.; Dhir, R.K.; Gill, J.P. Concrete surface treatment: Effect of exposure temperature on chloride diffusion resistance. Cem. Concr. Res. 1995, 25, 197-208. [CrossRef]

25. Moon, H.Y.; Shin, D.G.; Choi, D.S. Evaluation of the durability of mortar and concrete applied with inorganic coating material and surface treatment system. Constr. Build. Mater. 2007, 21, 362-369. [CrossRef]

26. Oshiro, T.; Tanigawa, S. Effect of surface coatings on the durability of concrete exposed to marine environment. In Concrete in Marine Environment, Proceedings of the Second International Conference on Concrete in Marine Environment (ACI SP-109), Okinawa, Japan, 21-26 August 1988; American Concrete Institute: Detroit, Michigan, USA, 1988; pp. 179-198.

27. Porter, L.C. Some surface treatments increase concrete durability. In Durability of Concrete (ACI SP-47); American Concrete Institute: Detroit, MI, USA, 1975; pp. 211-232.

28. Safiuddin, Md.; Soudki, K.A. Water vapor transmission and waterproofing performance of concrete sealer and coating systems. J. Civ. Eng. Manag. 2015, 21, 837-844. [CrossRef] 
29. Song, Z.; Xue, X.; Li, Y.; Yang, J.; He, Z.; Shen, S.; Jiang, L.; Zhang, W.; Xu, L.; Zhang, H.; et al. Experimental exploration of the waterproofing mechanism of inorganic sodium silicate-based concrete sealers. Constr. Build. Mater. 2016, 104, 276-283. [CrossRef]

30. Shields, M.A.; Leek, D.S.; Lambert, P. Coatings for the protection of structural materials. Constr. Maint. Repair 1992, 6, 2-9.

31. Suleiman, A.R.; Soliman, A.M.; Nehdi, M.L. Effect of surface treatment on durability of concrete exposed to physical sulfate attack. Constr. Build. Mater. 2014, 73, 674-681. [CrossRef]

32. Ho, D.W.S.; Harrison, R.S. Influence of surface coatings on carbonation of concrete. ASCE J. Mater. Civ. Eng. 1990, 2, 35-44. [CrossRef]

33. Zhou, Y.; Gencturk, B.; William, K.; Attar, A. Carbonation-induced and chloride-induced corrosion in reinforced concrete structures. ASCE J. Mater. Civ. Eng. 2015, 27, 04014245. [CrossRef]

34. Palle, S.; Hopwood, T., Jr. Coatings, Sealants and Fillers to Address Bridge Concrete Deterioration and Aesthetics-Phase 1; Research Report No. KTC06-36/SPR 291-04-1F; Kentucky Transportation Center, College of Engineering, University of Kentucky: Lexington, KY, USA, 2006; p. 26.

35. Wenzlick, J.D. Bridge Deck Concrete Sealers; Final Research Report RI 04-051; Missouri Department of Transportation: Jefferson City, MO, USA, 2007.

36. Attanayaka, A.M.U.B.; Duyar, O.; Liang, X.; Aktan, H.M.; Ng, K.Y.S. Fundamentals of use of penetrating sealants for concrete bridge deck protection. In Proceedings of the TRB 2003 Annual Meeting, Washington, DC, USA, 12-16 January 2003.

37. Cady, P.D. Sealers for Portland Cement Concrete Highway Facilities; NCHRP Synthesis of Highway Practice 209; Transportation Research Board (TRB), National Research Council: Washington, DC, USA, 1994.

38. Pritzl, M.D.; Tabatabai, H.; Ghorbanpoor, A. Long-term chloride profiles in bridge decks treated with penetrating sealer or corrosion inhibitors. Constr. Build. Mater. 2015, 101, 1037-1046. [CrossRef]

39. Filice, J.; Wong, J. Best Practice Guidelines for Selecting Concrete Bridge Deck Sealers; Alberta Transportation and Utilities: Edmonton, AB, Canada, 2001.

40. Valenza, J.J.; Scherer, G.W. A review of salt scaling: II. Mechanisms. Cem. Concr. Rese. 2007, 37, $1022-1034$. [CrossRef]

41. Thomas, M.D.A. Optimizing the Use of Fly Ash in Concrete; Portland Cement Association (PCA): Skokie, IL, USA, 2007; p. 24.

42. Wu, Z.; Shi, C.; Gao, P.; Wang, D.; Cao, Z. Effects of deicing salts on the scaling resistance of concrete. ASCE J. Mater. Civ. Eng. 2015, 27, 04014160. [CrossRef]

43. Bei, S.; Zhixiang, L. Investigation on spalling resistance of ultra-high-strength concrete under rapid heating and rapid cooling. Case Stud. Constr. Mater. 2016, 4, 146-153. [CrossRef]

44. Portland Cement Association (PCA). Control of air content in concrete. Concr. Technol. Today 1998, 19, 1-3.

45. Concrete Slab Surface Defects: Causes, Prevention, Repair. Concrete Information; PCA R\&D Serial No. 2155; Portland Cement Association (PCA): Skokie, IL, USA, 2001; p. 16.

46. EKström, J.; Rempling, R.; Plos, M. Spalling in concrete subjected to shock wave blast. Eng. Struct. 2016, 122, 72-82. [CrossRef]

47. Delamination of Troweled Concrete Surfaces (CIP-20); National Ready Mixed Concrete Association (NRMCA): Silver Spring, MD, USA, 2004; p. 2.

48. Larosche, C.J. Types and causes of cracking in reinforced concrete. In Failure, Distress, and Repair of Concrete Structures; Delatte, N., Ed.; Woodhead Publishing Limited: Cambridge, UK, 2009; pp. 57-83.

49. Bentz, D.P.; Weiss, W.J. Internal Curing: A 2010 State-of-the Art Review; NISTIR 7765; National Institute of Standards and Technology: Gaithersburg, MD, USA, 2011; p. 82.

50. Crazing Concrete Surfaces (CIP-3); National Ready Mixed Concrete Association (NRMCA): Silver Spring, MD, USA, 2009; p. 2.

51. Melchers, R.E.; Li, C.Q. Reinforcement corrosion initiation and activation times in concrete structures exposed to severe marine environments. Cem. Concr. Res. 2009, 39, 1068-1076. [CrossRef]

52. Pruckner, F.; Gjørv, O.E. Effect of $\mathrm{CaCl}_{2}$ and $\mathrm{NaCl}$ additions on concrete corrosivity. Cem. Concr. Res. 2004, 34, 1209-1217. [CrossRef]

53. Saremi, M.; Mahallati, E. A study on chloride-induced depassivation of mild steel in simulated concrete pore solution. Cem. Concr. Res. 2002, 32, 1915-1921. [CrossRef] 
54. Alonso, C.; Andrade, C.; Rodriguez, J.; Diez, J.M. Factors controlling cracking of concrete affected by reinforcement corrosion. Mater. Struct. 1998, 31, 435-441. [CrossRef]

55. Liu, Y.; Weyers, R.E. Modeling the time-to-corrosion cracking in chloride contaminated reinforced concrete structures. ACI Mater. J. 1998, 95, 675-681.

56. Allan, M.L. Probability of corrosion induced cracking in reinforced concrete. Cem. Concr. Res. 1995, 25, 1179-1190. [CrossRef]

57. Cabrera, J.G. Deterioration of concrete due to reinforcement steel corrosion. Cem. Concr. Compos. 1996, 18, 47-59. [CrossRef]

58. Chi, J.M.; Huang, R.; Yang, C.C. Effects of carbonation on mechanical properties and durability of concrete using accelerated testing method. J. Mar. Sci. Technol. 2002, 10, 14-20.

59. Safiuddin, M.D. Performance of galvanized steel reinforcing bars against corrosion in concrete. BRAC Univ. J. 2005, 2, 93-102.

60. Pietrosanto, J. Rust Coloured Stains on the Surface of Exposed Aggregate Concrete; Vic Mix, TJM Operations Pty Ltd.: Victoria, Australia, 2010; p. 6.

61. Wong, H.S.; Zhao, Y.X.; Karimi, A.R.; Buenfeld, N.R.; Jin, W.L. Rust distribution in corrosion-induced cracking concrete. In Steel Corrosion-Induced Concrete Cracking; Butterworth Heinemann: Oxford, UK, 2016; pp. 93-109.

62. Soudki, K.A.; Jeffs, P.; Safiuddin, M.D. Concrete Coating Systems on Region of Waterloo Bridges; Final Research Report Submitted to the Region of Waterloo; Department of Civil and Environmental Engineering, Faculty of Engineering, University of Waterloo: Waterloo, ON, Canada, 15 December 2011.

63. Discoloration (CIP-23); National Ready Mixed Concrete Association (NRMCA): Silver Spring, MD, USA, 2007; p. 2.

64. Cwalina, B. Biodeterioration of concrete, brick and mineral-based building materials. In Understanding Biocorrosion: Fundamentals and Applications; Woodhead Publishing Limited: Cambridge, UK, 2014; pp. 281-312.

65. Annila, P.J.; Hellemaa, M.; Pakkala, T.A.; Lahdensivu, J.; Suonketo, J.; Pentti, M. Extent of moisture and mould damage in structures of public building. Case Stud. Constr. Mater. 2017, 6, 103-108. [CrossRef]

66. Thompson, J.L.; Silsbee, M.R.; Gill, P.M.; Scheetz, B.E. Characterization of silicate sealers on concrete. Cem. Concr. Res. 1997, 27, 1561-1567. [CrossRef]

67. Safiuddin, Md.; Soudki, K.A. Sealer and coating systems for the protection of bridge structures. Int. J. Phys. Sci. 2011, 6, 8188-8199. [CrossRef]

68. Nair, P.S.; Gettu, R. Commercially available waterproofing agents in India: A review. Indian Concr. J. 2016, 90, 36-53.

69. Ameri, M.; Behnood, A. Laboratory studies to investigate the properties of CIR mixes containing steel slag as a substitute for virgin aggregates. Constr. Build. Mater. 2012, 26, 475-480. [CrossRef]

70. Behnood, A.; Gharehveran, M.M.; Asl, F.G.; Ameri, M. Effects of copper slag and recycled concrete aggregate on the properties of CIR mixes with bitumen emulsion, rice husk ash, Portland cement, and fly ash. Constr. Build. Mater. 2015, 96, 172-180. [CrossRef]

71. Basheer, P.A.M.; Basheer, L.; Cleland, D.J.; Long, A.E. Surface treatments for concrete: Assessment methods and reported performance. Constr. Build. Mater. 1997, 11, 413-429. [CrossRef]

72. Garbacz, A.; Courard, L.; Bissonnette, B. A surface engineering approach applicable to concrete repair engineering. Bull. Pol. Acad. Sci. Tech. Sci. 2013, 61, 73-84. [CrossRef]

73. ASTM C672/C672M Standard Test Method for Scaling Resistance of Concrete Surfaces Exposed to De-icing Chemicals; ASTM International: West Conshohocken, PA, USA, 2012.

74. ASTM C642 Standard Test Method for Density, Absorption and Voids in Hardened Concrete; ASTM International: West Conshohocken, PA, USA, 2013.

75. AASHTO T259 Standard Method of Test for Resistance of Concrete to Chloride Ion Penetration; American Association of State Highway and Transportation Officials: Washington, DC, USA, 2002.

76. ASTM D822/D822M Standard Practice for Filtered Open-Flame Carbon-Arc Exposures of Paint and Related Coatings; ASTM International: West Conshohocken, PA, USA, 2013.

77. ASTM B117 Standard Practice for Operating Salt Spray (Fog) Apparatus; ASTM International: West Conshohocken, PA, USA, 2016. 
78. Test Procedure for Measuring the Vapour Transmission, Waterproofing and Hiding Power of Concrete Sealers (BT001); Technical Standards Branch, Alberta Transportation and Utilities (ATU): Edmonton, Alberta, Canada, 2000.

79. Test Procedure for Measuring the Waterproofing Performance of Core Samples Taken from Sealed Concrete Surfaces (BT005); Technical Standards Branch, Alberta Transportation and Utilities (ATU): Edmonton, AB, Canada, 2000.

80. AASHTO T161 Standard Method of Test for Resistance of Concrete to Rapid Freezing and Thawing; American Association of State Highway and Transportation Officials: Washington, DC, USA, 2008.

81. ASTM C666/C666M Standard Test Method for Resistance of Concrete to Rapid Freezing and Thawing; ASTM International: West Conshohocken, PA, USA, 2015.

82. ASTM D2243 Standard Test Method for Freeze-Thaw Resistance of Water-Borne Coatings; ASTM International: West Conshohocken, PA, USA, 2014.

83. AASHTO T260 Sampling and Testing for Chloride Ion in Concrete and Concrete Raw Materials; American Association of State Highway and Transportation Officials: Washington, DC, USA, 2016.

84. AASHTO T277 Standard Method of Test for Electrical Indication of Concrete's Ability to Resist Chloride Ion Penetration; American Association of State Highway and Transportation Officials: Washington, DC, USA, 2015.

85. ASTM C1152/C1152M Standard Test method for Acid-Soluble Chloride in Mortar and Concrete; ASTM International: West Conshohocken, PA, USA, 2012.

86. ASTM C1202 Standard Test Method for Electrical Indication of Concrete's Ability to Resist Chloride Ion Penetration; ASTM International: West Conshohocken, PA, USA, 2012.

87. ASTM C1543 Standard Test Method for Determining the Penetration of Chloride Ion into Concrete by Ponding; ASTM International: West Conshohocken, PA, USA, 2010.

88. ASTM D4587 Standard Practice for Fluorescent UV-Condensation Exposures of Paint and Related Coating; ASTM International: West Conshohocken, PA, USA, 2011.

89. ASTM D4585/D4585M Standard Practice for Testing Water Resistance of Coatings using Controlled Condensation; ASTM International: West Conshohocken, PA, USA, 2013.

90. ASTM D6489 Standard Test Method for Determining the Water Absorption of Hardened Concrete Treated with a Water-Repellent Coating; ASTM International: West Conshohocken, PA, USA, 2012.

91. ASTM D1653 Standard Test Methods for Water Vapor Transmission of Organic Coating Films; ASTM International: West Conshohocken, PA, USA, 2013.

92. ASTM E96/E96M Standard Test Methods for Water Vapor Transmission of Materials; ASTM International: West Conshohocken, PA, USA, 2016.

93. ASTM D3273 Standard Test Method for Resistance to Growth of Mold on the Surface of Interior Coating in an Environmental Chamber; ASTM International: West Conshohocken, PA, USA, 2016.

94. ASTM D3274 Standard Test Method for Evaluating Degree of Surface Disfigurement of Paint Films by Microbial (Fungal and Algal) Growth or Soil and Dirt Accumulation; ASTM International: West Conshohocken, PA, USA, 2013.

95. ASTM D4541 Standard Test Method for Pull-off Strength of Coatings Using Portable Adhesion Testers; ASTM International: West Conshohocken, PA, USA, 2009.

96. ASTM D2794 Standard Test Method for Resistance of Coatings to the Effects of Rapid Deformation (Impact); ASTM International: West Conshohocken, PA, USA, 2010.

97. ASTM D1654 Standard Test Method for Evaluation of Painted or Coated Specimens Subjected to Corrosive Environments; ASTM International: West Conshohocken, PA, USA, 2016.

(C) 2017 by the author. Licensee MDPI, Basel, Switzerland. This article is an open access article distributed under the terms and conditions of the Creative Commons Attribution (CC BY) license (http:/ / creativecommons.org/licenses/by/4.0/). 